\title{
Bimolecular Quadruplexes and Their Transitions to Higher-Order Molecular Structures Detected by ESI-FTICR-MS
}

\author{
Xinhua Guo, Shuying Liu, and Zhan Yu \\ Changchun Center of Mass Spectrometry, Changchun Institute of Applied Chemistry, Chinese Academy \\ of Sciences, Changchun, China
}

Four individual quadruplexes, which are self-assembled in ammonium acetate solution from telomeric sequences of closely related DNA strands- $d\left(G_{4} T_{4} G_{4}\right), d\left(G_{3} T_{4} G_{4}\right), d\left(G_{3} T_{4} G_{3}\right)$, and $d\left(G_{4} T_{4} G_{3}\right)$ - have been detected in the gas phase using electrospray ionization Fourier transform ion cyclotron resonance mass spectrometry (ESI-FTICR-MS). The bimolecular quadruplexes associate with the same number of $\mathrm{NH}_{4}^{+}$in the gas phase as NMR shows that they do in solution. The quadruplex structures formed in solution are maintained in the gas phase. Furthermore, the mass spectra show that the bimolecular quadruplexes generated by the strands $d\left(G_{3} T_{4} G_{3}\right)$ and $d\left(G_{4} T_{4} G_{3}\right)$ are unstable, being converted into trimolecular and tetramolecular structures with increasing concentrations of $\mathrm{NH}_{4}^{+}$in the solution. Circular dichroism (CD) spectra reveal structural changes during the process of strand stoichiometric transitions, in which the relative orientation of strands in the quadruplexes changes from an antiparallel to a parallel arrangement. Such changes were observed for the strand $d\left(G_{4} T_{4} G_{3}\right)$, but not for the strand $d\left(G_{3} T_{4} G_{3}\right)$. The present work provides a significant insight into the formation of various DNA quadruplexes, especially the higher-order species. (J Am Soc Mass Spectrom 2007, 18, 1467-1476) @ 2007 American Society for Mass Spectrometry

$\mathrm{D}$ NA quadruplexes, which are formed by guaninerich oligonucleotide strands by the stacking of hydrogen-bonded G-quartets (Figure 1a), have been of great interest to researchers because of their biological significance and structural applications [1-3]. Of particular interest is a telomeric DNA that consists of repeating sequences, such as TTAGGG in vertebrates and TTTTGGGG in Oxytricha. These sequences have been proven to fold into quadruplexes in vitro and potentially have the function of inhibiting telomerase activities. The telomerase, a reverse enzyme expressed in more than $80 \%$ of tumor cells, responds for the replication of the telomeric DNA and has been considered as a target for anticancer drug design [4, 5]. Guanine-rich oligonucleotides can also self-associate into higher-order structures, such as supermolecular G-wires [6], which serve as artificial ion channels and ion receptors and which have a wide range of applications in medicine, materials science, and nanotechnology $[2,7,8]$.

DNA quadruplex structures can be formed from one, two, or four oligonucleotide strands and are stabilized by coordinated monovalent cations acting between adjacent G-quartets [1,9-11]. The strands with single repeating guanine sequences usually arrange them-

Address reprint requests to Dr. Shuying Liu, Changchun Institute of Applied Chemistry, Chinese Academy of Sciences, Changchun Center of Mass Spectrometry, 5265 Remin Street, Changchun, Jiln 130022, China. E-mail: syliu@ciac.jl.cn selves from the $5^{\prime}$ to the $3^{\prime}$ end in parallel four-stranded quadruplexes, whereas the strands with more than two tracks of repeating guanine units can form a number of quadruplexes that are distinguished by their strand number, strand orientation, and loop types. The structural topologies of DNA quadruplexes also drastically change with slight changes of the DNA sequences, with the nature of the cationic species and with their concentrations in solution. As a result, the structures of DNA quadruplexes are far from being fully recognized and have been of concern to researchers because of their potential implications in biological and structural applications.

Development in electrospray ionization mass spectrometry (ESI-MS) has been shown to be superior in the analysis of DNA noncovalent complexes in terms of speed, sensitivity, stoichiometry, and specificity compared to other analytical techniques [12]. Previous work by ourselves and others have shown that some specific DNA conformations, such as hairpins, triplexes, and quadruplexes formed in solution, can survive in the gas phase [13-20]. This prompted us to explore the structural properties of DNA quadruplexes with ESI-MS so as to add new information concerning them.

In the present work, we chose the strands $\mathrm{d}\left(\mathrm{G}_{4} \mathrm{~T}_{4} \mathrm{G}_{4}\right)$, $\mathrm{d}\left(\mathrm{G}_{3} \mathrm{~T}_{4} \mathrm{G}_{4}\right), \mathrm{d}\left(\mathrm{G}_{3} \mathrm{~T}_{4} \mathrm{G}_{3}\right)$, and $\mathrm{d}\left(\mathrm{G}_{4} \mathrm{~T}_{4} \mathrm{G}_{3}\right)$, which are closely related to the telomeric sequence $\mathrm{d}\left(\mathrm{G}_{4} \mathrm{~T}_{4} \mathrm{G}_{4}\right)$, and formed them by removing a guanine residue from the $5^{\prime}$ end, the $3^{\prime}$ end, or both ends of the strand. NMR 


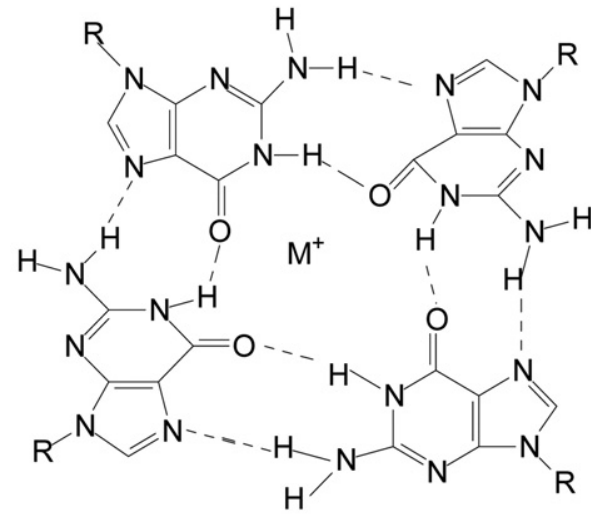

(a)

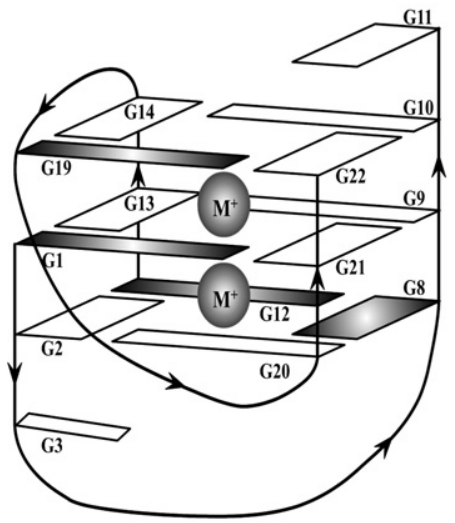

(c)

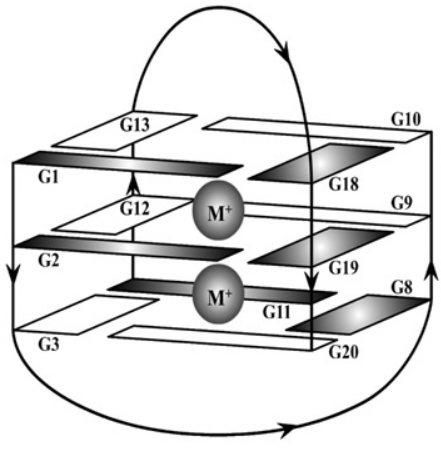

(d)

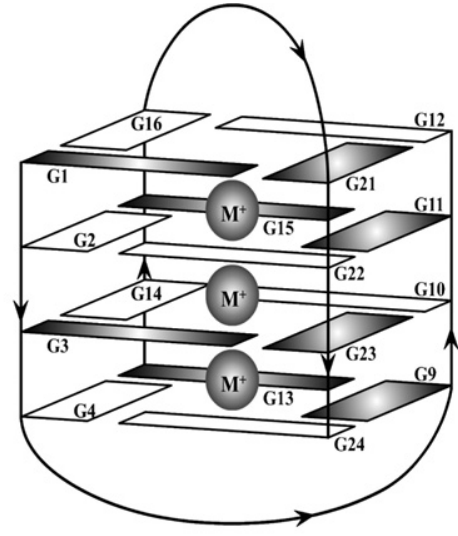

(b)

Figure 1. (a) G-quartet structures formed by four hydrogen-bonded guanines. Bimolecular quadruplexcation complexes formed by the sequences $(\mathbf{b}) d\left(G_{4} G_{4}\right),(\mathbf{c}) d\left(G_{3} G_{4}\right),(d) d\left(G_{3} G_{3}\right)$, and (e) $d\left(G_{4} G_{3}\right)$. The gray balls represent the coordinated monovalent cations. The arrows indicate the strand directions. The parallelograms stand for guanine and the shaded one represents the syn orientation. All of the thymines in the loop have been omitted for simplicity.

spectroscopy showed that each of the DNA strands self-assembled into individual bimolecular quadruplexes, with distinct topologies, in the presence of monovalent cations [21-28]. The monovalent cations are necessary to coordinate in the core of the quaduplexes and so to stabilize the structures. [Note: Subsequently in this paper, the sequences will be described as $d\left(G_{4} G_{4}\right)$, $d\left(G_{3} G_{4}\right), d\left(G_{3} G_{3}\right)$, and $d\left(G_{4} G_{3}\right)$, leaving out the consistent intermediary $\mathrm{T}_{4}$.]

The bimolecular $\left[\mathrm{d}\left(\mathrm{G}_{4} \mathrm{G}_{4}\right)\right]_{2}$ is formed by two foldedback hairpins, with two $T_{4}$ strands looped over and under the quadruplex connecting diagonal ends of it (Figure 1b) [21, 22]; four guanines in each strand adopt alternate syn-anti glycosidic torsion angles and fourlayer stacked G-quartets sandwich three monovalent cations. This structure distinguishes it from the bimolecular $\left[\mathrm{d}\left(\mathrm{G}_{3} \mathrm{G}_{4}\right)\right]_{2}$, $\left[\mathrm{d}\left(\mathrm{G}_{3} \mathrm{G}_{3}\right)\right]_{2}$, and $\left[\mathrm{d}\left(\mathrm{G}_{4} \mathrm{G}_{3}\right)\right]_{2}$ that coordinate two cations between three stacked G-quartets. The structure of $\left[\mathrm{d}\left(\mathrm{G}_{3} \mathrm{G}_{3}\right)\right]_{2}$ differs from that of the $\left[\mathrm{d}\left(\mathrm{G}_{4} \mathrm{G}_{4}\right)\right]_{2}$ by the absence of a middle G-quartet (Figure $1 \mathrm{~d})$, so that the guanine bases are arranged $5^{\prime}$-syn-syn- anti-loop-syn-anti-anti-3' in one strand and $5^{\prime}$-syn-antianti-loop-syn-syn-anti-3' in the other [23-26]. In contrast, the structure of the bimolecular $\left[\mathrm{d}\left(\mathrm{G}_{3} \mathrm{G}_{4}\right)\right]_{2}$ is special (Figure 1c), in that one guanine residue leaps over the middle G-quartet, turning an antiparallel strand parallel to its own half, and so that two dangling guanines reside at opposite ends of the quadruplex [27, 28]. The bimolecular $\left[d\left(G_{4} G_{3}\right)\right]_{2}$ also includes two dangling guanine residues, but these reside on the same side of the quadruplex (Figure 1e). The guanine bases in each strand of this alternate syn-anti glycosidic torsion angles along the stacking quartets [29]. NMR studies show that these bimolecular quadruplexes retain the same general folds in $\mathrm{Na}^{+}, \mathrm{K}^{+}$, or $\mathrm{NH}_{4}^{+}$solution (Figure $1 b-d)[22,24,25,28]$, except for the strand $d\left(G_{4} G_{3}\right)$, which folds into the bimolecular structure (Figure 1e) only in $\mathrm{Na}^{+}$solution, but forms multiple structures in the presence of $\mathrm{K}^{+}$and $\mathrm{NH}_{4}^{+}$[29]. Using ESI-MS, we expect to detect specific interactions between strand and strand, as well as between quadruplex and monovalent ammonium ion. 
Sen and Gilbert observed that the formation of the four-stranded parallel quadruplexes was anomalously dependent on the species of alkali metal cation in the solution. They proposed that the bimolecular foldback quadruplexes were "overstabilized" intermediates and expected that all of the quadruplexes that were formed by single- or double-folded strands could finally be converted to four-stranded parallel structures [30]. Miura et al., using Raman spectroscopy, detected the transition of the antiparallel bimolecular $\left[\mathrm{d}\left(\mathrm{G}_{4} \mathrm{G}_{4}\right)\right]_{2}$ to the parallel four-stranded structure in the solution containing $\mathrm{Na}^{+}$and $\mathrm{K}^{+}$by changing the $\mathrm{K}^{+} / \mathrm{Na}^{+}$ratio [31]. Miyoshi et al., using CD spectroscopy, observed a similar transition of the bimolecular $\left[d\left(G_{4} G_{4}\right)\right]_{2}$ to the four-stranded $\left[d\left(G_{4} G_{4}\right)\right]_{2}$ induced by the presence of $\mathrm{Ca}^{2+}[32]$.

The purpose of this work is to use ESI-FTICR-MS to examine the structural features of the sequences of four different but closely related strands. We detected the bimolecular quadruplexes in the gas phase that were associated with the specific number of ammonium ions as they had been detected in solution. Furthermore, we observed the higher-order species that are formed by the strands $d\left(G_{3} G_{3}\right)$ and $d\left(G_{4} G_{3}\right)$. The structural transitions that occurred in the conversion of the bimolecule to the higher-order tetramolecule were examined with CD spectroscopy. Thus, ESI-MS and CD combine to provide significant insights into the structural features of the DNA quadruplexes.

\section{Experimental}

\section{Sample Preparation}

Synthesized oligonucleotides $d\left(G_{4} T_{4} G_{4}\right), d\left(G_{3} T_{4} G_{4}\right)$, $\mathrm{d}\left(\mathrm{G}_{3} \mathrm{~T}_{4} \mathrm{G}_{3}\right)$, and $\mathrm{d}\left(\mathrm{G}_{4} \mathrm{~T}_{4} \mathrm{G}_{3}\right)$ (OPC grade), purchased from TaKaRa Biotechnology (Dalian, China) and used without further purification, were dissolved in Milli-Q water and stored as approximately $2 \mathrm{mM}$ concentrations. The exact concentration of each strand was determined based on its UV absorbances at $260 \mathrm{~nm}$ and the extinction coefficients for them obtained from the website (http:/ / scitools.idtdna.com/scitools / Applications / oligoAnalyzer).

DNA quadruplexes were prepared by heating the solutions containing $200 \mu \mathrm{M}$ of each DNA strand and 40-200 mM ammonium acetate in a $90{ }^{\circ} \mathrm{C}$ water bath for $10 \mathrm{~min}$ and cooling the solution to room temperature. Then the samples were stored at $4{ }^{\circ} \mathrm{C}$ for more than $24 \mathrm{~h}$. For the MS analysis, the samples were diluted with an equal volume of methanol just before the sample being injected into the ESI source. For the CD detection, the samples were diluted with an equal volume of water.

\section{Mass Spectrometry}

DNA samples were analyzed with an IonSpec HiRes Fourier transform ion cyclotron resonance mass spectrom- eter (FT-ICR-MS) (Lake Forest, CA, USA) equipped with a 7.0 T shielded superconducting magnet and a Micromass Z-spray electrospray source. The instrumental conditions used for this experiment were as follows: directly infused sample rate, $3 \mu \mathrm{L} / \mathrm{min}$; spray voltage, $2300 \mathrm{~V}$; source and probe temperatures, 80 and $100{ }^{\circ} \mathrm{C}$, respectively; the sample cone voltage varied from -20 to $-50 \mathrm{~V}$. Sample spectra were taken in the negative-ion mode. The generated ions were accumulated in the external hexapole for $4000 \mathrm{~ms}$ and then were shuttered into the analyzer cell in company with 30-ms pulse of nitrogen gas to center the ions and to improve sensitivities. Each spectrum was one scan acquisition with $1024 \mathrm{~K}$ data points at the ADC rate of $1 \mathrm{MHz}$.

\section{Circular Dichroism (CD) Spectroscopy}

The CD spectra were recorded on a J-810 circular dichroism spectropolarimeter (Jasco, Tokyo, Japan) using a micro quartz cell with a $0.5-\mathrm{cm}$ path length. The wavelength was scanned from 200 to $340 \mathrm{~nm}$ at a rate of $500 \mathrm{~nm} / \mathrm{min}$. Each spectrum was the average of three runs. The buffer spectrum was subtracted from each of the sample spectra.

Note that the ESI-MS data were obtained in 50\% methanol solution, whereas the CD data were acquired in aqueous solution, with 50\% methanol added just before the spray to enhance sensitivity. No spectral changes were detected when methanol amounts were reduced from 50 to $20 \%$ except a reduction of the signal intensities. The 50\% methanol was also used instead of $\mathrm{H}_{2} \mathrm{O}$ just before CD detection and a similar spectrum was obtained (see spectrum in the Supplementary Information section which can be found in the electronic version of this article).

\section{Results and Discussion}

\section{Detection of the Bimolecular DNA Quadruplexes}

Figure $^{\circ} 2 \mathrm{a}-\mathrm{d}^{\circ}$ shows $^{\circ}$ the $^{\circ}$ ESI-mass $^{\circ}$ spectra $^{\circ}$ of $^{\circ} 100^{\circ} \mu \mathrm{M}$ DNA strands $\mathrm{d}\left(\mathrm{G}_{4} \mathrm{G}_{4}\right), \mathrm{d}\left(\mathrm{G}_{3} \mathrm{G}_{4}\right), \mathrm{d}\left(\mathrm{G}_{3} \mathrm{G}_{3}\right)$, and $\mathrm{d}\left(\mathrm{G}_{4} \mathrm{G}_{3}\right)$, which were determined in $20 \mathrm{mM}$ ammonium acetate, in a negative-ion mode and at relatively low sample cone $^{\circ}$ voltages ${ }^{\circ}$ of $^{\circ}-20^{\circ} \mathrm{V}^{\circ}{ }^{\circ}$ From $^{\circ}$ Figure $^{\circ} 2 \mathrm{a}^{\circ}$ it $^{\circ} \mathrm{can}^{\circ}$ be $^{\circ}$ seen that the $\mathrm{d}\left(\mathrm{G}_{4} \mathrm{G}_{4}\right)$ generates abundant -5 charged peaks at $m / z 1521.0610(100 \%)$ and at $m / z 1524.4682(36 \%)$, as well as a -4 charged peak at $m / z$ 1905.8914 (7\%), corresponding to the $\left[\left(\mathrm{G}_{4} \mathrm{G}_{4}\right)_{2}+2 \mathrm{NH}_{4}\right]^{5-},\left[\left(\mathrm{G}_{4} \mathrm{G}_{4}\right)_{2}+\right.$ $\left.3 \mathrm{NH}_{4}\right]^{5-}$, and $\left[\left(\mathrm{G}_{4} \mathrm{G}_{4}\right)_{2}+3 \mathrm{NH}_{4}\right]^{4-}$ ions, respectively. (Here we omit each ion's proton counterions for the sake of simplicity.) Similarly, the $d\left(G_{3} G_{4}\right)$ generates an abundant -5 charged peak at $m / z 1389.4386(100 \%)$ and a -4 charged peak at $m / z 1737.0653(37 \%)$, corresponding to $\left[\left(\mathrm{C}_{3} \mathrm{G}_{4}\right)_{2}+2 \mathrm{NH}_{4}\right]^{5-}$ and $\left[\left(\mathrm{G}_{3} \mathrm{G}_{4}\right)_{2}+2 \mathrm{NH}_{4}\right]^{4-}$ ions, respectively ${ }^{\circ}$ Figure $\left.^{\circ} 2 b\right)$.

In contrast, the mass spectra of the sequences $\mathrm{d}\left(\mathrm{G}_{3} \mathrm{G}_{3}\right)^{\circ}$ and $^{\circ} \mathrm{d}\left(\mathrm{G}_{4} \mathrm{G}_{3}\right)^{\circ}\left(\text { Figure }^{\circ} 2 \mathrm{c}^{\circ} \text { and }^{\circ} \mathrm{d}\right)^{\circ}$ are $^{\circ}$ more $^{\circ}$ com- 
(a)

$$
\left[\left(\mathrm{G}_{4} \mathrm{G}_{4}\right)_{2}+2 \mathrm{NH}_{4}\right]^{5-}
$$

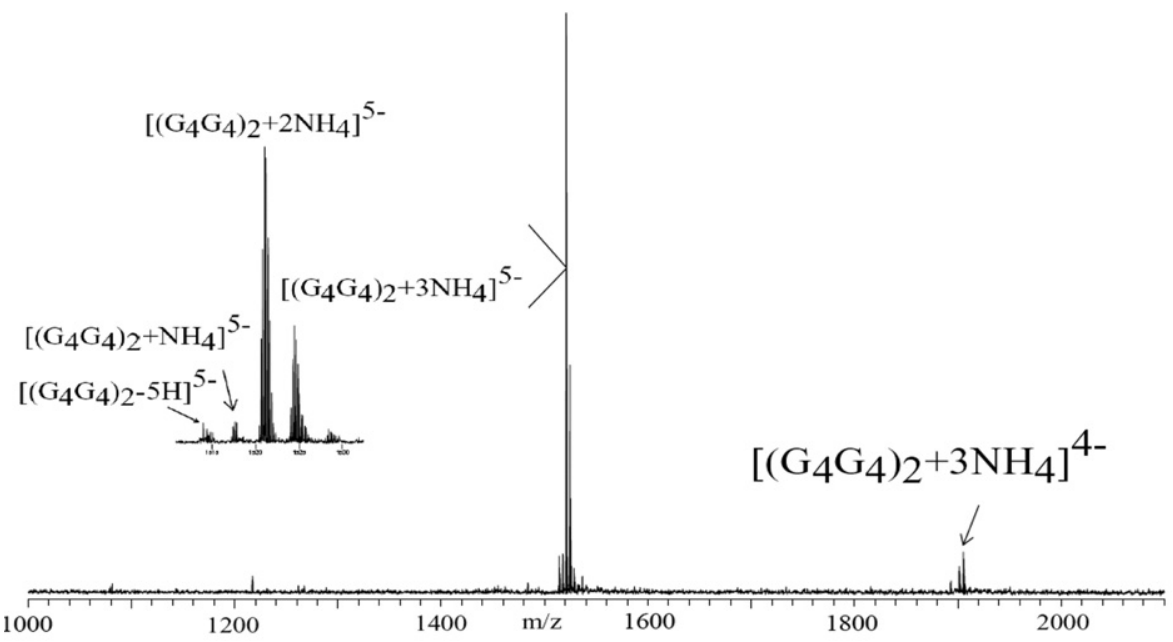

(b) $\quad\left[\left(\mathrm{G}_{3} \mathrm{G}_{4}\right)_{2}+2 \mathrm{NH}_{4}\right]^{5-}$

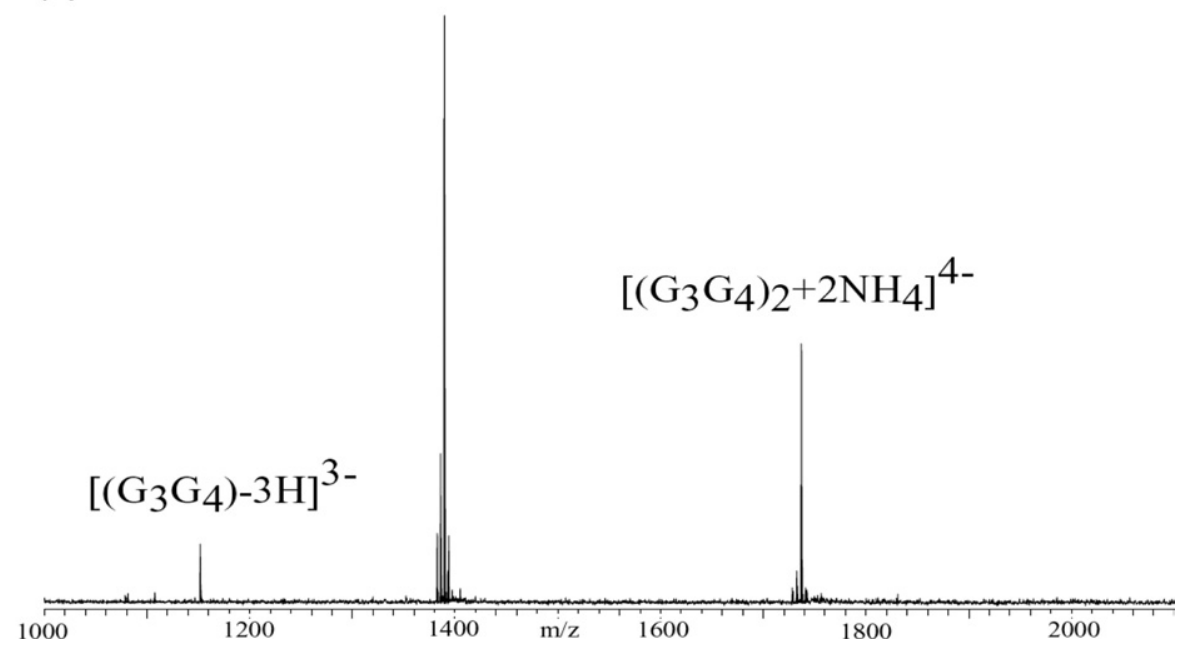

Figure 2. The mass spectra of $200 \mu \mathrm{M}$ DNA strands incubated in $40 \mathrm{mM} \mathrm{NH}_{4}^{+}$solution for $24 \mathrm{~h}$ and detected in a solution diluted with an equal volume of methanol at $-20 \mathrm{~V}$ sample cone voltage: (a) $\mathrm{d}\left(\mathrm{G}_{4} \mathrm{G}_{4}\right)$, (b) $\mathrm{d}\left(\mathrm{G}_{3} \mathrm{G}_{4}\right),(\mathbf{c}) \mathrm{d}\left(\mathrm{G}_{3} \mathrm{G}_{3}\right)$, and $(\mathbf{d}) \mathrm{d}\left(\mathrm{G}_{4} \mathrm{G}_{3}\right)$. The inserted spectra are zooms of the peaks indicated.

plicated. For the strand $d\left(G_{3} G_{3}\right)$, besides the detections of the bimolecular quadruplex complex ions $\left[\left(\mathrm{G}_{3} \mathrm{G}_{3}\right)_{2}+\right.$ $\left.\mathrm{NH}_{4}\right]^{5-}$ at $\mathrm{m} / \mathrm{z} 1254.2230(10 \%),\left[\left(\mathrm{G}_{3} \mathrm{G}_{3}\right)_{2}+2 \mathrm{NH}_{4}\right]^{5-}$ at $\mathrm{m} / \mathrm{z} 1257.6279(5 \%)$, and $\left[\left(\mathrm{G}_{3} \mathrm{G}_{3}\right)_{2}+2 \mathrm{NH}_{4}\right]^{4-}$ at $\mathrm{m} / \mathrm{z}$ $1572.2722(100 \%)$, the less abundant trimolecular and tetramolecular complex ions $\left[\left(\mathrm{G}_{3} \mathrm{G}_{3}\right)_{3}+2 \mathrm{NH}_{4}\right]^{5-}$ at $\mathrm{m} / \mathrm{z}$ $1883.7307(5 \%),\left[\left(\mathrm{G}_{3} \mathrm{G}_{3}\right)_{4}+4 \mathrm{NH}_{4}\right]^{7-}$ at $\mathrm{m} / \mathrm{z} 1797.1869$ $(3 \%)$, and $\left[\left(\mathrm{G}_{3} \mathrm{G}_{3}\right)_{4}+5 \mathrm{NH}_{4}\right]^{6-}$ at $\mathrm{m} / \mathrm{z} 2099.7590(9 \%)$ are also $^{\circ}$ detected $^{\circ}\left(\right.$ Figure $\left.^{\circ} 2 \mathrm{c}\right) .^{\circ}{ }^{\circ}$ The ${ }^{\circ}$ strand ${ }^{\circ} \mathrm{d}\left(\mathrm{G}_{4} \mathrm{G}_{3}\right)$ generates bimolecular peaks for $\left[\left(\mathrm{G}_{4} \mathrm{G}_{3}\right)_{2}+2 \mathrm{NH}_{4}\right]^{5-}$ at $\mathrm{m} / \mathrm{z} 1389.4346$ $(34 \%)$ and $\left[\left(\mathrm{G}_{4} \mathrm{G}_{3}\right)_{2}+2 \mathrm{NH}_{4}\right]^{4-}$ at $\mathrm{m} / z 1737.0342(53 \%)$, as well as less abundant trimolecular and tetramolecular peaks for $\left[\left(\mathrm{G}_{4} \mathrm{G}_{3}\right)_{3}+3 \mathrm{NH}_{4}\right]^{5-}$ at $\mathrm{m} / z 2084.6541(8 \%)$, $\left[\left(\mathrm{G}_{4} \mathrm{G}_{3}\right)_{4}+6 \mathrm{NH}_{4}\right]^{7-}$ at $1990.2732(4 \%)$, and $\left[\left(\mathrm{G}_{4} \mathrm{G}_{3}\right)_{4}+\right.$ $\left.6 \mathrm{NH}_{4}\right]^{6-}{ }^{6}{ }^{\circ} \mathrm{m} / \mathrm{z} 2321.8962^{\circ}(3 \%)^{\circ}\left(\right.$ Figure $\left.^{\circ} 2 \mathrm{~d}\right){ }^{\circ}$ Here, ${ }^{\circ}$ the uneven isotopic distribution around the $\mathrm{m} / \mathrm{z} 1737.0342$ peak is evident. On the basis of accurate $\mathrm{m} / \mathrm{z}$ values, ion intensities and the space of adjacent isotopic peaks ( 0.25 or 0.50 ), the ion at $m / z 1737.0342$ was assigned to the bimolecular ion $\left[\left(\mathrm{G}_{4} \mathrm{G}_{3}\right)_{2}+2 \mathrm{NH}_{4}\right]^{4-}$, and its neighbor ion at $\mathrm{m} / \mathrm{z} 1736.7893$ was assigned to $\left[\left(\mathrm{G}_{4} \mathrm{G}_{3}\right)+\mathrm{NH}_{4}\right]^{2-}$. The detection of the abundant $\left[\left(\mathrm{G}_{4} \mathrm{G}_{3}\right)_{2}+\mathrm{NH}_{4}\right]^{2-}$ is interesting in that it may imply a specific structure of a single foldback strand that associates a $\mathrm{NH}_{4}^{+}$or suggest an association mechanism that moves from single to double to higher-order species.

Previously, a number of DNA quadruplexes have been detected in the gas phase. These gas-phase structures are considered to reflect the quadruplex structures in $^{\circ}$ solution ${ }^{\circ}[15-20] .{ }^{\circ} \mathrm{A}^{\circ}$ recent $^{\circ}$ quadruplex ${ }^{\circ}$ study ${ }^{\circ}$ by Bowers' group suggests that ESI can be used to characterize the quadruplexes and their interactions with ligands because the quadruplex ions at lower charge states maintain their structures through the electro- 
(c)

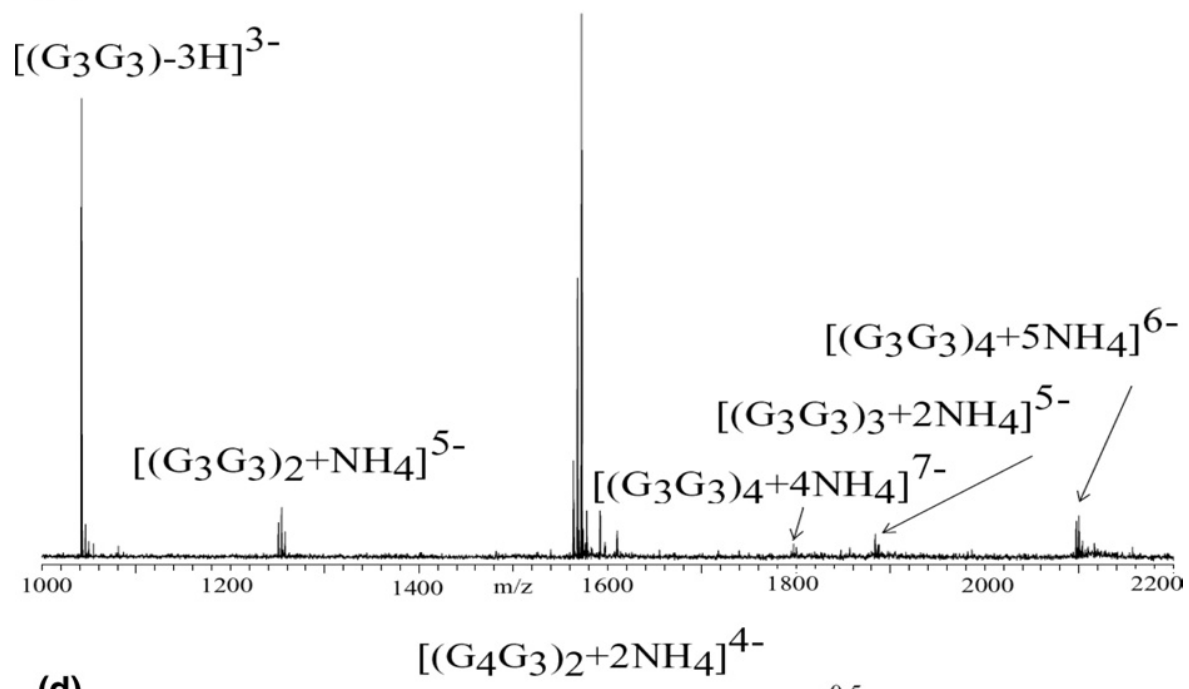

(d)

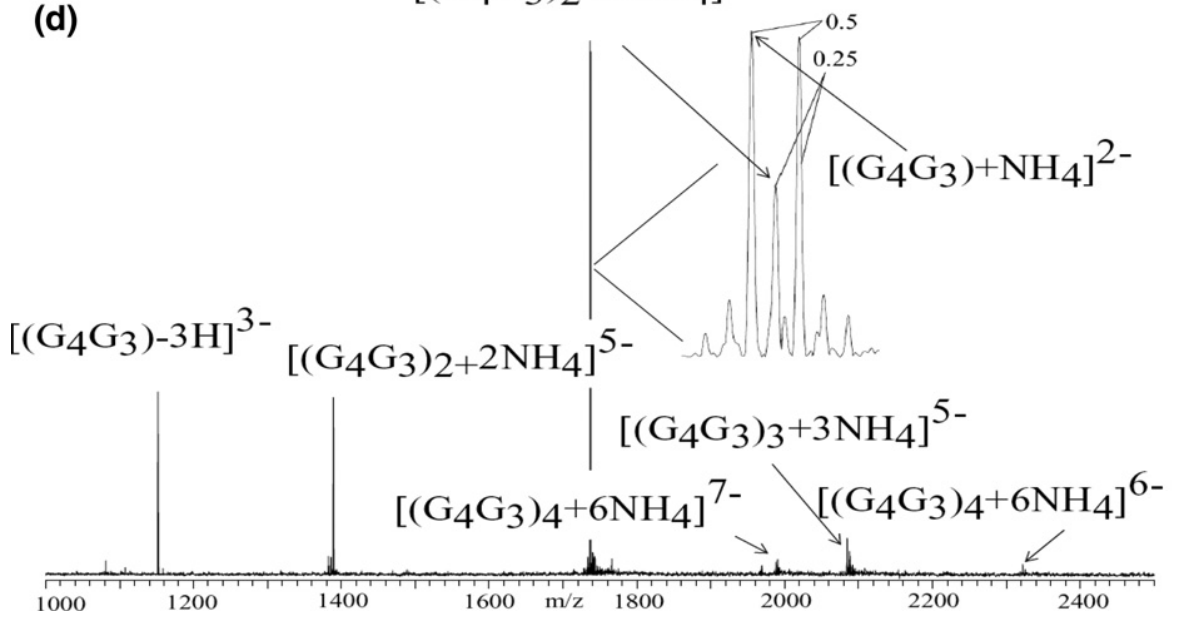

Figure 2. Continued.

spray and desolvation process if no activating energies are $^{\circ}$ applied ${ }^{\circ}$ to $^{\circ}$ the ${ }^{\circ}$ system $^{\circ}[19] .{ }^{\circ}$ In $^{\circ}$ the ${ }^{\circ}$ present $^{\circ}$ work, individual bimolecular quadruplexes are detected in the gas phase. NMR solution structures show that the four-sequence closely related DNA strands form distinct topological bimolecular quadruplexes in solution,

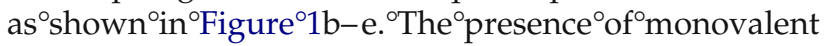
cations, such as $\mathrm{Na}^{+}, \mathrm{K}^{+}$, and $\mathrm{NH}_{4}^{+}$, is necessary to coordinate between adjacent G-quartets and to stabilize the quadruplex structure. In this case, the bimolecular $\left[\mathrm{d}\left(\mathrm{G}_{4} \mathrm{G}_{4}\right)\right]_{2}$ consists of four stacked G-quartets that ${ }^{\circ} \mathrm{can}^{\circ}$ associate $^{\circ}$ three $^{\circ}$ monovalent $^{\circ}$ cations $^{\circ}$ (Figure 1b), ${ }^{\circ}$ whereas ${ }^{\circ}$ the ${ }^{\circ}$ other $^{\circ}$ three ${ }^{\circ}$ bimolecular $^{\circ}$ quadruplexes, $\left[\mathrm{d}\left(\mathrm{G}_{3} \mathrm{G}_{4}\right)\right]_{2},\left[\mathrm{~d}\left(\mathrm{G}_{3} \mathrm{G}_{3}\right)\right]_{2}$, and $\left[\mathrm{d}\left(\mathrm{G}_{4} \mathrm{G}_{3}\right)\right]_{2}$, consist of three quartets that can coordinate two cations in solution $^{\circ}$ (Figure ${ }^{\circ} 1 \mathrm{c}-\mathrm{e}$ ).

On inspecting the abundant bimolecular peaks at the -5 and -4 charge states that are formed by each individual ${ }^{\circ}$ strand $^{\circ}\left(\right.$ Figure $^{\circ}$ 2a-d) - for $^{\circ}$ example,, $0\left(\mathrm{G}_{4} \mathrm{G}_{4}\right)_{2}+$ $\left.2 \mathrm{NH}_{4}\right]^{5-{ }^{\circ}}$ and $^{\circ}\left[\left(\mathrm{G}_{4} \mathrm{G}_{4}\right)_{2}+3 \mathrm{NH}_{4}\right]^{4-^{\circ}}$ (Figure $\left.{ }^{\circ} 2 \mathrm{a}\right)$ - $\mathrm{it}^{\circ}{ }^{\circ} \mathrm{s}^{\circ} \mathrm{ob}-$ served that the -4 charged ions associate with a specific number of ammonium ions and that the number just matches the number of cations coordinated by the quadruplexes $^{\circ}$ in $^{\circ}$ solution $^{\circ}\left(\text { Figure }^{\circ} 1 \mathrm{~b}-\mathrm{e}\right)^{\circ}[21-29]^{\circ} .{ }^{\circ}$ The complex ion $\left[\left(\mathrm{G}_{4} \mathrm{G}_{4}\right)_{2}+3 \mathrm{NH}_{4}\right]^{4-}$ associates with $3 \mathrm{NH}_{4}^{+}$ ions, whereas the other complex ions $\left[\left(\mathrm{G}_{3} \mathrm{G}_{4}\right)_{2}+2 \mathrm{NH}\right]^{4-}$, $\left[\left(\mathrm{G}_{3} \mathrm{G}_{4}\right)_{2}+2 \mathrm{NH}\right]^{4-}$, and $\left[\left(\mathrm{G}_{4} \mathrm{G}_{3}\right)_{2}+2 \mathrm{NH}\right]^{4-}$ associate with 2 $\mathrm{NH}_{4}^{+}$ions. Such specific associations were not observed for either linear or hairpin DNA strands in our previous work $^{\circ}[14] .{ }^{\circ}$ This $^{\circ}$ suggests $^{\circ}$ that $^{\circ}$ our $^{\circ}$ ESI-FTICR-MS ${ }^{\circ}$ has detected the specific interactions between the DNA complexes and $\mathrm{NH}_{4}^{+}$at lower sample cone voltage as they $^{\circ}$ are $^{\circ}$ formed $^{\circ}$ in $^{\circ}$ the $^{\circ}$ solution $^{\circ}\left(\right.$ Figure $\left.^{\circ} 1 \mathrm{~b}-\mathrm{e}\right) .^{\circ}$ Each bimolecular complex peak at the charge state of -5 associates with the same or fewer numbers of ammonium ions than the peak at the charge state of -4 , and the -5 charged complex ions are observed to lose $\mathrm{NH}_{4}^{+}$ more easily than the -4 charged complex ions when the sample cone voltages are elevated (spectra not shown). This indicates that the higher charged complex ions are less compact and less stable in the gas phase. This 


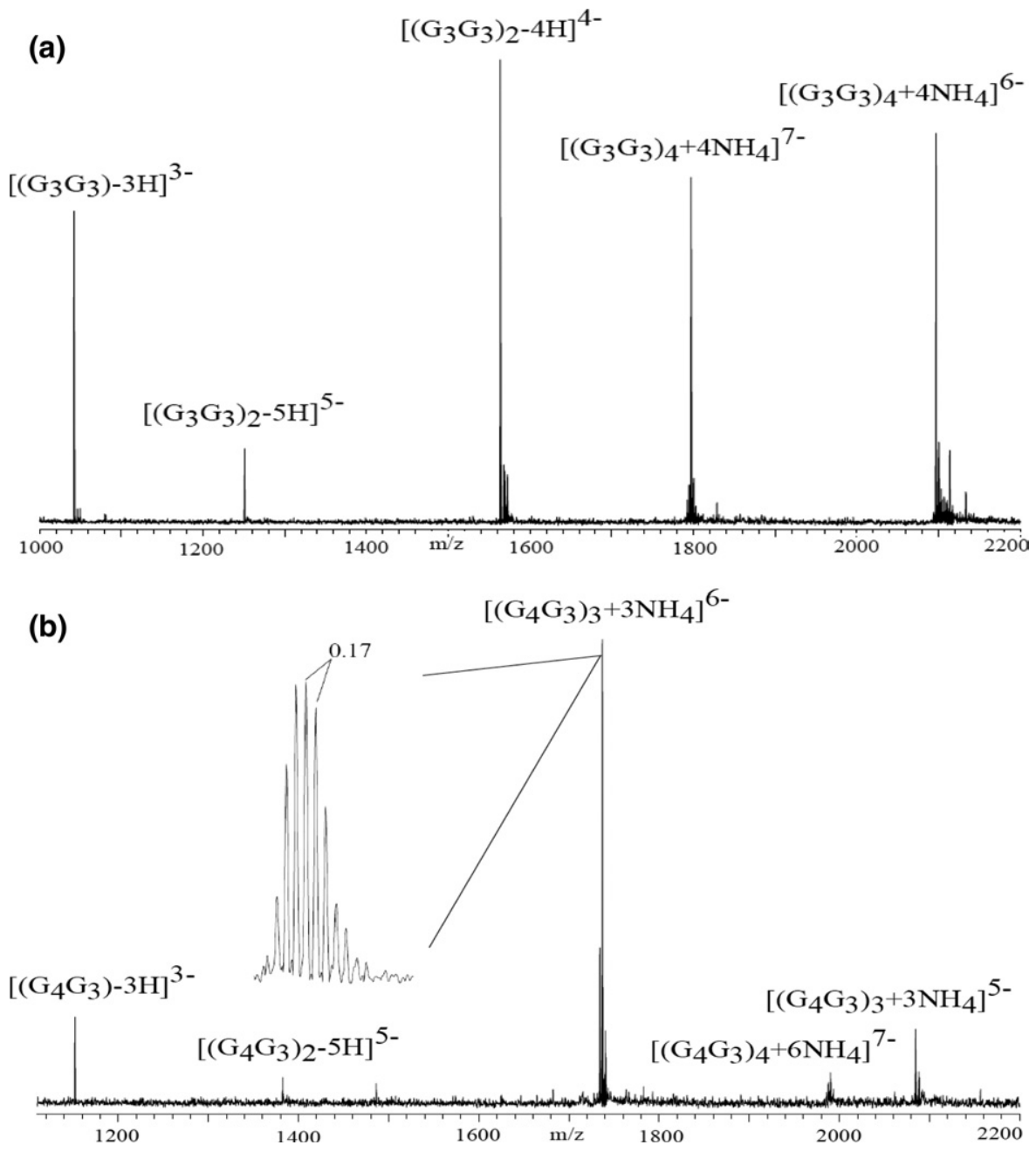

Figure 3. The mass spectra of $200 \mu \mathrm{M}$ DNA strands incubated in $100 \mathrm{mM} \mathrm{NH}_{4}^{+}$solution for $24 \mathrm{~h}$ and detected in a solution diluted with an equal volume of methanol at $-30 \mathrm{~V}$ sample cone voltage. The inserted spectra are zooms of the peaks indicated.

observation is consistent with detections using the ion mobility ${ }^{\circ}$ technique $[19]$.

\section{Detections of Trimolecular and Tetramolecular Species}

Besides the bimolecular species, the strands $d\left(G_{3} G_{3}\right)$ and $d\left(G_{4} G_{3}\right)$ generate less abundant trimolecular and tetramolecular peaks in $20 \mathrm{mM} \mathrm{NH}_{4}^{+}$solution'(Figure 2c and d). With increasing concentrations of $\mathrm{NH}_{4}^{+}$from 20 to $100 \mathrm{mM}$, the abundance of the higher-order ions, such as the trimolecular $\left[\left(\mathrm{G}_{4} \mathrm{G}_{3}\right)_{3}+3 \mathrm{NH}_{4}^{+}\right]$and tetramolecular $\left[\left(\mathrm{G}_{3} \mathrm{G}_{3}\right)_{4}+4 \mathrm{NH}_{4}^{+}\right]$and $\left[\left(\mathrm{G}_{4} \mathrm{G}_{3}\right)_{4}+6 \mathrm{NH}_{4}^{+}\right]$species increases, whereas the abundance of single and bimolecular ${ }^{\circ}$ ions ${ }^{\circ}$ decreases. ${ }^{\circ}$ Figure $^{\circ} 3^{\circ}$ shows $^{\circ}$ mass ${ }^{\circ}$ spectra ${ }^{\circ}$ of the strands $d\left(G_{3} G_{3}\right)$ and $d\left(G_{4} G_{3}\right)$ acquired in $50 \mathrm{mM}$ $\mathrm{NH}_{4}^{+}$and at a sample cone voltage of $-30 \mathrm{~V}$. Here we use cone voltage of $-30 \mathrm{~V}$ instead of $-20 \mathrm{~V}$ to get better spectra of higher-order species; in this case the $\mathrm{NH}_{4}^{+}$ ions escape from the bimolecular complexes. In contrast, the abundance of the bimolecular quadruplex ions increases for the strands $d\left(G_{4} G_{4}\right)$ and $d\left(G_{3} G_{4}\right)$ with increasing concentrations of $\mathrm{NH}_{4}^{+}$from 20 to $100 \mathrm{mM}$, but no higher-order species are detected (spectra not shown). Concentrations higher than $80 \mathrm{mM} \mathrm{NH}_{4}^{+}$in solution facilitate the formation of the bimolecular and the higher-order complexes and suppress the ion signals in the mass spectra.

Clearly, the concentration of $\mathrm{NH}_{4}^{+}$present in the solution plays an important role in promoting the stoichiometric transitions of the strands from the bimolecular to the higher-order species. Under our conditions, transitions were observed by ESI-MS only for the strands $d\left(G_{3} G_{3}\right)$ and $d\left(G_{4} G_{3}\right)$, but not for $d\left(G_{4} G_{4}\right)$ and $d\left(G_{3} G_{4}\right)$, even when the latter were incubated in the $\mathrm{NH}_{4}^{+}$solution for more than 10 days. Miura et al. found that the antiparallel bimolecular quadruplex formed by the strand $d\left(G_{4} G_{4}\right)$ was generated at low concentrations of $\mathrm{Na}^{+}$and $\mathrm{K}^{+}$, and that the bimolecular species was converted to the parallel four-stranded quadruplex when the concentrations of both alkali ions were increased in a range of $65-225 \mathrm{mM}$, the $\mathrm{K}^{+}$being more 
effective ${ }^{\circ}$ than $^{\circ}$ the $\mathrm{Na}^{+}{ }^{\circ}$ in $^{\circ}$ promoting ${ }^{\circ}$ the transition $^{\circ}[31]$. Miyoshi et al. observed similar structural transitions of the antiparallel bimolecular $\left[\left(\mathrm{G}_{4} \mathrm{G}_{4}\right)\right]_{2}$ to the parallel tetramolecular $\left[\mathrm{d}\left(\mathrm{G}_{4} \mathrm{G}_{4}\right)\right]_{4}$ and finally to a G-wire, and the transitions were induced by the presence of $\mathrm{Ca}^{2+}$ [32]..$^{\circ}$ Sen $^{\circ}$ and $^{\circ}$ Gilbert $^{\circ}$ proposed $^{\circ}$ that ${ }^{\circ}$ the ${ }^{\circ}$ foldback ${ }^{\circ}$ bimolecular quarduplexes were overstabilized intermediates and expected all of the quadruplexes formed by single, double, or four strands to be finally converted into four-stranded ${ }^{\circ}$ parallel $^{\circ}$ quadruplexes $^{\circ}[30] .{ }^{\circ} \operatorname{In}^{\circ}$ this $^{\circ}$ case, the transitions of the bimolecular species to the tetramolecular one are probably facilitated by specific structural and stability characteristics of the bimolecular quadruplexes. If $\left[\mathrm{d}\left(\mathrm{G}_{4} \mathrm{G}_{4}\right)\right]_{2}$ is compared with $\left[\mathrm{d}\left(\mathrm{G}_{3} \mathrm{G}_{4}\right)\right]_{2}$, $\left[\mathrm{d}\left(\mathrm{G}_{3} \mathrm{G}_{3}\right)\right]_{2}$, and $\left[\mathrm{d}\left(\mathrm{G}_{4} \mathrm{G}_{3}\right)\right]_{2}, \quad\left[\mathrm{~d}\left(\mathrm{G}_{4} \mathrm{G}_{4}\right)\right]_{2}$ contains one more G-quartet than the other bimolecular complexes and so should be more stable. On the other hand, three parallel strands in $\left[d\left(G_{3} G_{4}\right)\right]_{2}$ seem to make its specific structure more stable.

Mass spectra show that the strand $d\left(G_{3} G_{3}\right)$ forms trimolecular and tetramolecular complex ions. The trimolecular complex ion associates with $2 \mathrm{NH}_{4}^{+}$ions. The tetramolecular complex ion associates with a maximum of $5 \mathrm{NH}_{4}^{+}$ions ${ }^{\circ}$ (Figure $2 \mathrm{c}$ ); ${ }^{\circ}$ the ${ }^{\circ}$ species ${ }^{\circ}$ associated ${ }^{\circ}$ with $^{\circ} 4$ $\mathrm{NH}_{4}^{+}$ions is stable when the sample cone voltage is increased from -20 to $-30 \mathrm{~V}$. The strand $\mathrm{d}\left(\mathrm{G}_{4} \mathrm{G}_{3}\right)$ generates trimolecular ions associated with $3 \mathrm{NH}_{4}^{+}$ions and tetramolecular ions associated with $6 \mathrm{NH}_{4}^{+}$ions ${ }^{\circ}$ (Figures $2 \mathrm{~d}^{\circ}$ and $\left.^{\circ} 3 \mathrm{~b}\right) .^{\circ}$ The $^{\circ}$ bimolecular $^{\circ}\left[\mathrm{d}\left(\mathrm{G}_{4} \mathrm{G}_{3}\right)\right]_{2}$ contains two dangling guanine residues residing at the same end of the quadruplex. These guanines can pair with two other guanine residues, either from a foldback single strand or from another bimolecular quaduplex, to form a new G-quartet. Thus, the combination of two bimolecular quadruplexes can form seven layers of G-quartets associated with $6 \mathrm{NH}_{4}^{+}$ions, or the combination of a bimolecular quadruplex with a single strand can form four layers of G-quartets associated with $3 \mathrm{NH}_{4}^{+}$ions. Similarly, the tetramolecular $\left[\mathrm{d}\left(\mathrm{G}_{3} \mathrm{G}_{3}\right)\right]_{4}$ can be formed by the stacking of two $\left[d\left(G_{3} G_{3}\right)\right]_{2}$, which generates six layers of Gquartets and accommodates a maximum number of 5 $\mathrm{NH}_{4}^{+}$ions; it can also be formed by four parallel $\mathrm{d}\left(\mathrm{G}_{3} \mathrm{G}_{3}\right)$ stands and so accommodate $4 \mathrm{NH}_{4}^{+}$ions.

\section{Spectra of the Bimolecular and Higher-Order Species}

Numerous studies have shown that the circular dichroism (CD) technique is sensitive to the strand arrangement $^{\circ}$ in $^{\circ} \mathrm{DNA}^{\circ}$ quadruplexes $^{\circ}\left[9-11,{ }^{\circ} 18,{ }^{\circ} 32-40\right] .^{\circ}$ For example, Vorlíčková et al. studied various topologies of the quadruplexes formed by the human telomere DNA fragments $\mathrm{G}_{3}\left(\mathrm{TTAG}_{3}\right)_{n},{ }^{\circ}$ where ${ }^{\circ} n={ }^{\circ} 1-16^{\circ}[39]^{\circ}$ X $^{\circ} \mathrm{u}^{\circ} \mathrm{et}^{\circ} \mathrm{al}$., using the $\mathrm{CD}$ technique, examined the quadruplex structure generated by the human telomeric sequence d[AGGG(TTAGGG) 3 ] by substituting the G's with 8-bromoguanine [36]; this'structure had been 'controversial for a long time. They proposed that the $22 \mathrm{nt}$ in $\mathrm{K}^{+}$ forms a mixture of mixed-parallel/antiparallel and chair-type quadruplexes. Typically, the quadruplex in which four strands adopt the parallel arrangement generated a characteristic strong positive peak at 264 $\mathrm{nm}$ and a large negative peak at $240 \mathrm{~nm}$, whereas the quadruplex in which the strands adopt an antiparallel arrangement showed an intense positive peak at $295 \mathrm{~nm}$ and a large negative peak at $260 \mathrm{~nm}$.

Figure ${ }^{\circ}{ }^{\circ}$ shows ${ }^{\circ}$ the $\mathrm{CD}^{\circ}$ spectra ${ }^{\circ}$ of $200^{\circ} \mu \mathrm{M}^{\circ}$ samples $^{\circ}$ of DNA strands incubated in 40, 100, 160, and $200 \mathrm{mM}$ $\mathrm{NH}_{4}^{+}$for $24 \mathrm{~h}$ and detected in solutions diluted with equal volumes of $\mathrm{H}_{2} \mathrm{O}$. The strand $d\left(\mathrm{G}_{4} \mathrm{G}_{4}\right)$ forms an intense positive peak at $294 \mathrm{~nm}$ and a large negative peak $^{\circ}$ at $^{\circ} 260^{\circ} \mathrm{nm}^{\circ}\left(\right.$ Figure $\left.^{\circ} 4 \mathrm{a}\right),{ }^{\circ}$ as $^{\circ}$ reported ${ }^{\circ}$ previously $^{\circ}[32$, $\left.33,{ }^{\circ} 35\right]^{\circ}{ }^{\circ}$ suggesting $^{\circ}$ the $^{\circ}$ formation ${ }^{\circ}$ of $^{\circ}$ the $^{\circ}$ antiparallel bimolecular ${ }^{\circ}$ quadruplex $^{\circ}$ shown $^{\circ}{ }^{\circ}{ }^{\circ}$ Figure $^{\circ} 1 \mathrm{~b}$. $^{\circ}$ The ${ }^{\circ}$ transition of the antiparallel bimolecular $\left[\mathrm{d}\left(\mathrm{G}_{4} \mathrm{G}_{4}\right)\right]_{2}$ to the parallel four-stranded $\left[\mathrm{d}\left(\mathrm{G}_{4} \mathrm{G}_{4}\right)\right]_{4}$ was detected previously in the presence of certain concentrations of $\mathrm{K}^{+}$ and ${ }^{\circ} \mathrm{Ca}^{2+}{ }^{\circ}\left[31,{ }^{\circ} 32\right] .{ }^{\circ}$ In ${ }^{\circ}$ the ${ }^{\circ}$ present ${ }^{\circ}$ work, ${ }^{\circ}$ with ${ }^{\circ}$ increasing concentrations of $\mathrm{NH}_{4}^{+}$from 20 to $100 \mathrm{mM}$, both the intensities of the positive peak at $294 \mathrm{~nm}$ and of the negative peak at $260 \mathrm{~nm}$ decrease, suggesting the reduction of the concentrations of the bimolecules. However, no parallel four-stranded quadruplexes were eventually detected by ESI-MS.

The bimolecular $\left[\mathrm{d}\left(\mathrm{G}_{3} \mathrm{G}_{4}\right)\right]_{2}$ generates a characteristic CD spectrum with two strong positive peaks at $290^{\circ}$ and $260^{\circ} \mathrm{nm}$, 'respectively ${ }^{\circ}$ (Figure $4 \mathrm{~b}$ ), arising ' from the specific topology of three strands being aligned parallel $^{\circ}$ in $^{\circ}$ the $^{\circ}$ same $^{\circ}$ orientation $^{\circ}\left(\right.$ Figure $\left.^{\circ} 1 \mathrm{c}\right) .^{\circ}$ This typical CD spectrum generated by the specific type of strand arrangement has been used to characterize mixed-parallel/antiparallel quadruplex structures $\left[36,{ }^{\circ} 39,{ }^{\circ} 40\right] .^{\circ}$ The $^{\circ}$ intensities $^{\circ}$ of $^{\circ}$ both $^{\circ}$ positive $^{\circ}$ peaks increase with increasing concentrations of $\mathrm{NH}_{4}^{+}$, and no band transition is detected, suggesting that the bimolecular $\left[\mathrm{d}\left(\mathrm{G}_{3} \mathrm{G}_{4}\right)\right]_{2}$ is stable in a range of $\mathrm{NH}_{4}^{+}$of 20-100 mM.

CD spectra of the strand $d\left(G_{3} G_{3}\right)$ show a positive peak at $288 \mathrm{~nm}$ and a negative peak at $257 \mathrm{~nm}$, indicating the antiparallel arrangement of strands. The intensities of both peaks are enhanced when the bimolecular $\left[\mathrm{d}\left(\mathrm{G}_{3} \mathrm{G}_{3}\right)\right]_{2}$ is converted to the tetramolecular $\left[\mathrm{d}\left(\mathrm{G}_{3} \mathrm{G}_{3}\right)\right]_{4}$, and no band transitions are detected with increasing $\mathrm{NH}_{4}^{+}$concentration from 20 to $100 \mathrm{mM}$ (Figure ${ }^{\circ} 4 \mathrm{c}$ ).$^{\circ}$ This $^{\circ}$ suggest $^{\circ}$ that $^{\circ}$ no $^{\circ}$ changes $^{\circ}$ in $^{\circ}$ relative strand orientations occur during the process of stoichiometric and structural transitions.

Interestingly, the strand $\mathrm{d}\left(\mathrm{G}_{4} \mathrm{G}_{3}\right)$ shows a strong positive peak at $291 \mathrm{~nm}$, an intense positive peak at 260 nm, ${ }^{\circ}$ and ${ }^{\circ} a^{\circ}$ large $^{\circ}$ negative $^{\circ}$ peak $^{\circ}$ at $^{\circ} 237^{\circ} \mathrm{nm}^{\circ}$ (Figure ${ }^{\circ} 4 \mathrm{~d}$ ), suggesting the presence of a mixture of the parallel and antiparallel structures in a $20 \mathrm{mM}$ solution of $\mathrm{NH}_{4}^{+}$. Čmugelj et al. observed that the bimolecular $\left[\mathrm{d}\left(\mathrm{G}_{4} \mathrm{G}_{3}\right)\right]_{2}$ was formed only in $\mathrm{Na}^{+}$solution, although multiple structures were formed in the presence of $\mathrm{K}^{+}$and $\mathrm{NH}_{4}^{+}$ [29]. ${ }^{\circ}$ The $^{\circ}$ enhancement $^{\circ}$ of ${ }^{\circ}$ the ${ }^{\circ}$ positive $^{\circ}$ peak $^{\circ}$ at $^{\circ} 264^{\circ} \mathrm{nm}$ and the reduction of the positive peak at $291 \mathrm{~nm}$ with 


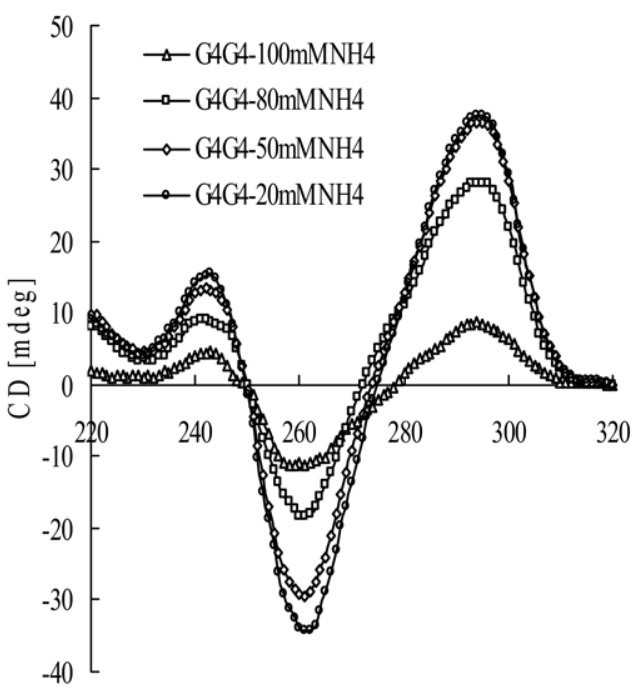

Wavelength (nm)

(a)

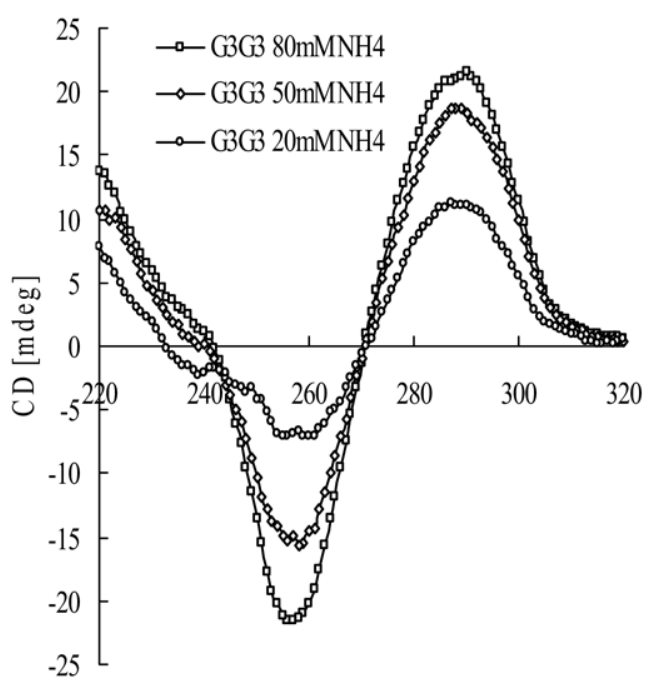

Wavelength (nm)

(c)

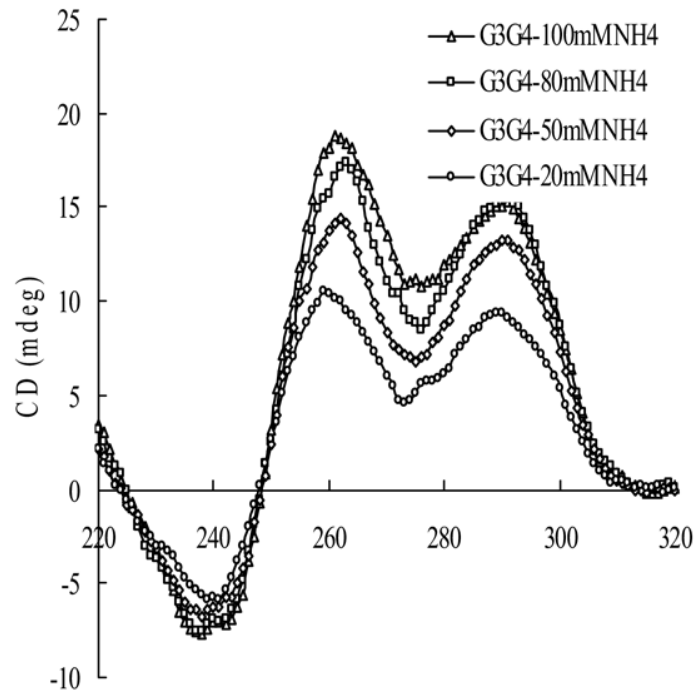

Wavelength (nm)

(b)

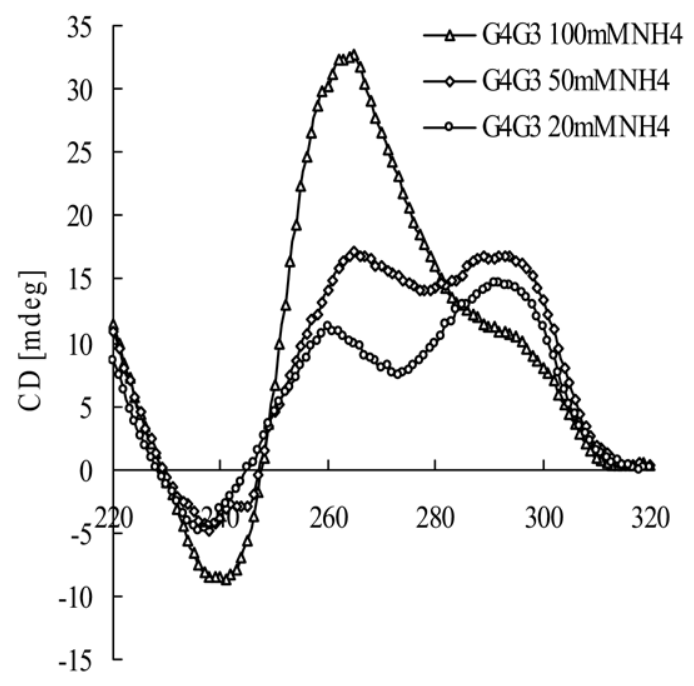

Wavelength (nm)

(d)

Figure 4. CD spectra of $200 \mu \mathrm{M}$ DNA strands incubated in 40 (circles), 100 (diamonds), 160 (squares), and 200 (triangles) $\mathrm{mM} \mathrm{NH}_{4}^{+}$solution for $24 \mathrm{~h}$ and detected in solutions diluted with equal volumes of $\mathrm{H}_{2} \mathrm{O}:(\mathbf{a}) \mathrm{d}\left(\mathrm{G}_{4} \mathrm{G}_{4}\right)$, (b) $\mathrm{d}\left(\mathrm{G}_{3} \mathrm{G}_{4}\right),(\mathbf{c}) \mathrm{d}\left(\mathrm{G}_{3} \mathrm{G}_{3}\right)$, and (d) $\mathrm{d}\left(\mathrm{G}_{4} \mathrm{G}_{3}\right)$.

increasing concentrations of $\mathrm{NH}_{4}^{+}$from 20 to $100 \mathrm{mM}$ indicate a structural transition in which the strands realign from the antiparallel to the parallel arrangement.

Consequently, on the basis of the number of $\mathrm{NH}_{4}^{+}$ ions attached in the higher-order quadruplexes and the $\mathrm{CD}$ spectra, we propose that the tetramolecular $\left[\mathrm{d}\left(\mathrm{G}_{3} \mathrm{G}_{3}\right)\right]_{4}$ involves the stacking of two bimolecular $\left[\mathrm{d}\left(\mathrm{G}_{3} \mathrm{G}_{3}\right)\right]_{2}$ quadruplexes. During the association process, the relative orientation of the strands does not change. The trimolecular $\left[\mathrm{d}\left(\mathrm{G}_{3} \mathrm{G}_{3}\right)\right]_{3}$ is less abundant in the mass spectra and is probably formed by an association of the bimolecular quadruplex with a single strand. Its structure is not clear and needs further investigation.

The tetramolecular $\left[\left(\mathrm{G}_{4} \mathrm{G}_{3}\right)\right]_{4}$ is formed by the association of two bimolecular $\left[\left(\mathrm{G}_{4} \mathrm{G}_{3}\right)\right]_{2}$ quadruplexes, whereas the trimolecular $\left[\left(\mathrm{G}_{4} \mathrm{G}_{3}\right)\right]_{3}$ involves the association of the bimolecular quadruplex with a single strand of a newly formed G-quartet. During this association process, the strand orientation changes from an antiparallel to a parallel arrangement.

Sen and Gilbert propose a formation mechanism of the quadruplex from a single- to a double- to a fourstranded structure in which the formation of the bimo- 
lecular structure is the rate-limiting step resulting from the quadratic dependency on the strand concentration in the assembly process of the four-stranded quadruplexes. As an intermediate, the bimolecular structure

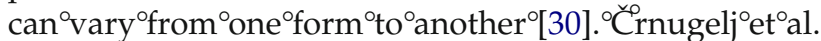
observed that the bimolecular quadruplex $\left[\mathrm{d}\left(\mathrm{G}_{4} \mathrm{G}_{3}\right)\right]_{2}$ (Figure $\left.{ }^{\circ} 1 \mathrm{e}\right)^{\circ}$ was $^{\circ}$ formed ${ }^{\circ}$ only ${ }^{\circ}$ in $^{\circ}$ the ${ }^{\circ} \mathrm{Na}^{+}{ }^{\circ}$ solution, ${ }^{\circ}$ and that multiple structures were generated in the presence of $\mathrm{NH}_{4}^{+}$and ${ }^{\circ} \mathrm{K}^{+}{ }^{\circ}$ [29]..$^{\circ}$ The ${ }^{\circ}$ transition ${ }^{\circ}$ of ${ }^{\circ}$ the ${ }^{\circ}$ antiparallel bimolecular $\left[\mathrm{d}\left(\mathrm{G}_{4} \mathrm{G}_{4}\right)\right]_{2}$ to the parallel four-standed $\left[\mathrm{d}\left(\mathrm{G}_{4} \mathrm{G}_{4}\right)\right]_{4}$ was detected when the cation type or the concentration ${ }^{\circ}$ was $^{\circ}$ altered $^{\circ}\left[31,{ }^{\circ} 32\right] .{ }^{\circ}$ Miyoshi $^{\circ}$ et $^{\circ}$ al. ${ }^{\circ}$ suggest that two $\mathrm{Ca}^{2+}$ ions bond to the fold bimolecular quaduplex $\left[\mathrm{d}\left(\mathrm{G}_{4} \mathrm{G}_{4}\right)\right]_{2}$ and unfold the structure; the strands then rearrange alignment in the denatured state and pair with other strands to form more stable parallel structures ${ }^{\circ}[32] .{ }^{\circ} \mathrm{Xu}^{\circ}$ et $^{\circ}$ al. $^{\circ}$ indicate ${ }^{\circ} \mathrm{a}^{\circ}$ possible ${ }^{\circ}$ shift $^{\circ}$ between the mixed-parallel/antiparallel and the chairtype quadruplexes formed by the human telomere sequence ${ }^{\circ}$ in $^{\circ} \mathrm{K}^{+\circ}$ ion $^{\circ}$ solution $^{\circ}[36]^{\circ} .{ }^{\circ}$ In $^{\circ}$ the ${ }^{\circ}$ present $^{\circ}$ work, we show that two of the four bimolecular quadruplexes are not terminal products and are converted to more stable structures. The transition rates probably depend on the stabilities and specific structures of the bimolecular quadruplexes, as well as on the solution conditions. We observed that the presence of certain amounts of $\mathrm{NH}_{4}^{+}$initiated the transitions of less stable bimolecular $\left[\mathrm{d}\left(\mathrm{G}_{3} \mathrm{G}_{3}\right)\right]_{2}$ and $\left[\mathrm{d}\left(\mathrm{G}_{4} \mathrm{G}_{3}\right)\right]_{2}$ to the higher-order structures. The bimolecular $\left[\mathrm{d}\left(\mathrm{G}_{4} \mathrm{G}_{4}\right)\right]_{2}$ conversion to the tetramolecular $\left[\mathrm{d}\left(\mathrm{G}_{4} \mathrm{G}_{4}\right)\right]_{4}$ was $^{\circ}$ reported $^{\circ}\left[31,{ }^{\circ} 32\right] .{ }^{\circ} \mathrm{No}$ transitions of the bimolecular $\left[\mathrm{d}\left(\mathrm{G}_{3} \mathrm{G}_{4}\right)\right]_{2}$ have been detected. During the transition process, the bimolecular quadruplexes are likely denatured by the coexisting cations, and then in an unfolded state the loops and the strands rearrange so as to generate more stable higherorder structures. This work has shown that the loop types of the bimolecular $\left[\mathrm{d}\left(\mathrm{G}_{3} \mathrm{G}_{3}\right)\right]_{2}$ have probably changed; thus, two bimolecules associate tightly and generate the stable tetramolecular quadruplex. In contrast, the bimolecular $\left[\mathrm{d}\left(\mathrm{G}_{4} \mathrm{G}_{3}\right)\right]_{2}$ varies its strand orientation, associating with a single strand or with itself to form the stable trimolecular and tetramolecular structures.

\section{Conclusion}

The combination of ESI mass spectrometry and CD spectropolarimetry techniques have provided significant stoichiometric and structural information on the DNA quadruplexes that are self-assembled by the DNA strands that are closed related in sequence. The sequence with two tracks of repeating G's facilitates a foldback to form bimolecular quadruplexes. However, some foldback bimolecular structures are not stable and are further converted into higher-order species, such as trimolecular and tetramolecular structures. The concentration and the nature of the coexisting cation play an important role in both stabilizing the structure and initiating the structural transitions. This present work provides an insight into the formation of the higher- order quadruplexes and may reveal important information as to how DNA sequences respond to environmental conditions to form various quadruplexes, as well as to how the quadruplexes align in the linear chromosome or other organisms for specific functions. These results also show that ESI-MS is a very rapid, accurate, and sensitive technique for providing structural information concerning DNA quadruplexes.

\section{Acknowledgments}

This work was supported by National Natural Science Foundation of China Grant 20575066.

\section{References}

1. Neidle, S.; Parkinson, G. N. The Structure of Telomeric DNA. Curr. Opin. Struct. Biol. 2003, 13, 275-283.

2. Davis, J. T. G-Quartets 40 Years Later: From $5^{\prime}$-GMP to Molecular Biology and Supramolecular Chemistry. Angew. Chem. Int. Ed. 2004, 43, $668-698$.

3. Arthanari, H.; Bolton, P. H. Functional and Dysfunctional Roles of Quadruplex DNA in Cells. Chem. Biol. 2001, 8, 221-230.

4. Neidle, S.; Parkinson, G. Telomere Maintenance as a Target for Anticancer Drug Discovery. Nat. Rev. Drug Discovery 2002, 1, 83-93.

5. Rezler, E. M.; Bearss, D. J.; Hurley, L. H. Telomere Inhibition and Telomere Disruption as Processes for Drug Targeting. Annu. Rev. Pharmacol. 2003, 43, 359-379.

6. Henderson, E.; Marsh, T. C. G-Wires: Self-Assembly of a Telomeric Oligonucleotide, d(GGGGTTGGGG), into Large Superstructures. Biochemistry 1994, 33, 10718-10724.

7. Forman, S. L.; Fettinger, J. C.; Pieaccini, S.; Gottarelli, G.; Davis, J. T. Toward Artificial Ion Channels: A Lipophilic G-Quadruplex. J. Am. Chem. Soc. 2000, 122, 4060-4067.

8. Shi, X.; Mullaugh, K. M.; Fettinger, J. C.; Jiang, Y.; Hofstadler, S. A.; Davis, J. T. Lipophilic G-Quadruplexes Are Self-Assembled Ion Pair Receptors, and the Bound Anion Modulates the Kinetic Stability of These Complexes. J. Am. Chem. Soc. 2003, 125, 10830-10841.

9. Keiiry, M. A. Quadruplex Structures in Nucleic Acids. Biopolymers 2001, 56, 123-146.

10. Burge, S.; Parkinson, G. N.; Hazel, P.; Todd, A. K.; Neidle, S. Survey and Summary Quadruplex DNA: Sequence, Topology and Structure. Nucleic Acids Res. 2006, 34, 5402-5415.

11. Hardin, C. C.; Perry, A. G.; White, K. Themodynamic and Kinetic Chracterization of the Dissociation and Assembly of Quadruplex Nucleic Acids. Biopolymers 2001, 56, 147-194.

12. Hofstadler, S. A.; Griffey, R. H. Analysis of Noncovalent Complexes of DNA and RNA by Mass Spectrometry. Chem. Rev. 2001, 101, 377-390.

13. Guo, X.; Bruist, M. F.; Davis, D. L.; Bentzley, C. M. Secondary Structural Characterization of Oligonucleotide Strands Using Electrospray Ionization Mass Spectrometry. Nucleic Acids Res. 2005, 33, 3659-3666.

14. Guo, X.; Liu, Z.; Liu, S.; Bentzley, C. M.; Bruist, M. F. Structural Features of the L-Argininamide-Binding DNA Aptamer Studied with ESI-FTMS. Anal. Chem. 2006, 78, 7259-7266.

15. Rosu, F.; Gabelica, V.; Houssier, C.; Colson, P.; Pauw, E. D. Triplex and Quadruplex DNA Structures Studied by Electrospray Mass Spectrometry. Rapid Commun. Mass Spectrom. 2002, 16, 1729-1736.

16. Baker, E. S.; Bernstein, S. L.; Cabelica, V.; De Pauw, E.; Bowers, M. T. G-Quadruplexes in Telomeric Repeats Are Conserved in a Solvent-Free Environment. Int. J. Mass Spectrom. 2006, 253, 225-237.

17. Vairamani, M.; Gross, M. L. G-Quadruplex Formation of ThrombinBinding Aptamer Detected by Electrospray Ionization Mass Spectrometry. J. Am. Chem. Soc. 2003, 125, 42-43.

18. Krishnan-Ghosh, Y.; Liu, D.; Balasubramanian, S. Formation of an Interlocked Quadruplex Dimer by d(GGGT). J. Am. Chem. Soc. 2004, 126, 11009-11016.

19. Gabelica, V.; Baker, E. S.; Teulade-Fichou, M.-P.; De Pauw, E.; Bowers, M. T. Stabilization and Structure of Telomeric and C-Myc Region Intramolecular G-Quadruplexes: The Role of Central Cations and Small Planar Ligands. J. Am. Chem. Soc. 2007, 129, 895-904.

20. David, W. M.; Brodbelt, J.; Kerwin, S.; Thomas, P. W. Investigation of Quadruplex Oligonucleotide-Drug Interactions by Electrospray Ionization Mass Spectrometry. Anal. Chem. 2002, 74, 2029-2033.

21. Smith, F. W.; Feigon, J. Quadruplex Structure of Oxytricha Telomeric DNA Oligonucleotides. Nature 1992, 356, 164-168.

22. Schultze, P.; Hud, N. V.; Smith, F. W.; Feigon, J. The Effect of Sodium, Potassium and Ammonium Ions on the Conformation of the Dimeric Quadruplex Formed by the Oxytricha Nova Telomere Repeat Oligonucleotide d $\left(\mathrm{G}_{4} \mathrm{~T}_{4} \mathrm{G}_{4}\right)$. Nucleic Acids Res. 1999, 27, 3018-3028.

23. Smith, F. W.; Lau, F. W.; Feigon, J. $d\left(G_{3} T_{4} G_{3}\right)$ Forms an Asymmetric Diagonally Looped Dimeric Quadruplex with Guanosine 5'-Syn-Syn- 
Anti and 5'-Syn-Anti-Anti N-Glycosidic Conformations. Proc. Natl. Acad. Sci. U.S.A. 1994, 91, 10546-10550.

24. Scaria, P. V.; Shire, S. J.; Shafer, R. H. Quadruplex Structure of $\mathrm{d}\left(\mathrm{G}_{3} \mathrm{~T}_{4} \mathrm{G}_{3}\right)$ Stabilized by $\mathrm{K}^{+}$or $\mathrm{Na}^{+}$is an Asymmetric Hairpin Dimer. Proc. Natl. Acad. Sci. U.S.A. 1992, 89, 10336-10340.

25. Hud, N. V.; Smith, F. W.; Anet, F. A. L.; Feigon, J. The Selectivity for K ${ }^{+}$ versus $\mathrm{Na}^{+}$in DNA Quadruplexes Is Dominated by Relative Free Energies of Hydration: A Thermodynamic Analysis by ${ }^{1} \mathrm{H}$ NMR. Biochemistry 1996, 35, 15383-15390.

26. Strahan, G. D.; Shafer, R. H.; Keniry, M. A. Structural Properties of the $\left[\mathrm{d}\left(\mathrm{G}_{3} \mathrm{~T}_{4} \mathrm{G}_{3}\right)\right]_{2}$ Quadruplex: Evidence for Sequential Syn-Syn Deoxyguanosines. Nucleic Acids Res. 1994, 22, 5447-5455.

27. Crnugelj, M.; Šket, P.; Plavec, J. Small Change in a G-rich Sequence, a Dramatic Change in Topology: New Dimeric G-Quadruplex Folding Motif with Unique Loop Orientations. J. Am. Chem. Soc. 2003, 125, 7866-7871.

28. Šket, P. Črnugelj, M. Plavec, $\mathrm{J} . \mathrm{d}\left(\mathrm{G}_{3} \mathrm{~T}_{4} \mathrm{G}_{4}\right)$ Forms Unusual Dimeric G-Quadruplex Structure with the Same General Fold in the Presence of $\mathrm{K}^{+}, \mathrm{Na}^{+}$or $\mathrm{NH}_{4}^{+}$Ions. Bioorg. Med. Chem. 2004, 12, 5735-5744.

29. Črnugelj, M.; Hud, N. V.; Plavec, J. The Solution Structure of $\mathrm{d}\left(\mathrm{G}_{4} \mathrm{~T}_{4} \mathrm{G}_{3}\right)_{2}$ : A Bimolecular G-Quadruplex with a Novel Fold. J. Mol. Biol. 2002, 320, 911-924.

30. Sen, D.; Gilbert, W. A Sodium-Potassium Switch in the Formation of Four-Stranded G4-DNA. Nature 1990, 344, 410-414.

31. Miura, T.; Benevides, J. M.; Thomas, G. J., Jr. A Phase Diagram for Sodium and Potassium Ion Control of Polymorphism in Telomeric DNA. J. Mol. Biol. 1995, 248, 233-238.

32. Miyoshi, D.; Nakao, A.; Sugimoto, N. Structural Transition Form Antiparallel to Parallel G-Quadruplex of $\mathrm{d}\left(\mathrm{G}_{4} \mathrm{~T}_{4} \mathrm{G}_{4}\right)$ Induced by $\mathrm{Ca}^{+}$. Nucleic Acids Res. 2003, 31, 1156-1163.
33. Petraccone, L.; Erra, E.; Esposito, V.; Randazzo, A.; Mayol, L.; Nasti, L. Barone, G.; Ciancola, C. Stability and Structure of Telomeric DNA Sequences Forming Quadruplexes Containing Four G-Tetrads with Different Topological Arrangement. Biochemistry 2004, 43, 4877-4884.

34. Porumb, H.; Monnot, M.; Fermandiian, S. Circular Dichroism Signatures of Features Simultaneously Present in Structured Guanine-Rich Oligonucleotides: A Combined Spectroscopic and Electrophoretic Approach. Electrophoresis 2002, 23, 1013-1020.

35. Dapić, V.; Abdomerović, V.; Marrington, R.; Peberdy, J.; Rodger, A.; Trent, J. O.; Bates, J. Biophysical and Biological Properties of Quadruplex Oligonucleotides. Nucleic Acids Res. 2003, 31, 2097-2107.

36. Xu, Y.: Noguchi, Y.: Sugiyama, H. The New Models of the Human Telomere d[AGGG(TTAGGG)3] in $\mathrm{K}^{+}$solution. Bioorg. Med. Chem. 2006 $14,5584-5591$.

37. Phan, A. T.; Kuryavyi, V.; Ma, J.-B.; Faure, A.; Andréola, M.-L.; Patel, D. J. An Interlocked Dimeric Parallel-Stranded DNA Quadruplex: A Potent Inhibitor of HIV-1 Interase. Proc. Natl. Acad. Sci. U.S.A. 2005, 102 , 634-639.

38. Protozanova, E.; Macgregor, R. B., Jr. Circular Dichroism of DNA Frayed Wires. Biophys. J. 1998, 75, 982-989.

39. Vorlíčková, M.; Chládková, J.; Kejnovská, I., Fialová, M.; Kypr, J. Guanine Tetraplex Topology of Human Telomere DNA Is Governed by the Number of (TTAGGG) Repeats. Nucleic Acids Res. 2005, 33, 58515860.

40. Dai, J.; Dexheimer, T. S.; Chen, D.; Carver, M.; Ambrush, A.; Jones, R. A.; Yang, D. An Intermolecular G-Quadruplex Structure with Mixed Parallel/Antiparallel G-strands Formed in the Human BCL-2 Promoter Region in Solution. J. Am. Chem. Soc. 2006, 128, 1096-1098. 